УДК 374.7.091

DOI:

Лариса Довгань, кандидат педагогічних наук, доцент кафедри украӥнської та іноземних мов Вінницького національного аграрного університету

\title{
СИСТЕМА НЕФОРМАЛЬНОЇ ОСВІТИ ДОРОСЛИХ У СІЛЬСЬКІЙ МІСЦЕВОСТІ
}

У статті розглядаються проблеми освіти дорослих у сільській місиевості. Проаналізовано роль неформальної освіти в освіті дорослих. Наведено чинники стрімкого розвитку неформальної освіти. Висвітлено філософію сільськогосподарського дорадниитва та позитивний закордонний досвід організаиіі його ефективної взаємодї̈ із неформальною освітою дорослих. Виявлено спорідненість основних иілей сільськогосподарської дорадчої діяльності та неформальної освіти дорослих у сільській місиевості та визначено, що неформальні освітні програми є основним інструментом їх досягнення. Наведено особливості неформальних освітніх програм сільськогосподарських дорадчих служб для дорослого сільського населення.

Ключові слова: освіта; освіта дорослих; неформальна освіта; освітні програми; сільська місиевість, сільськогосподарське дорадниитво.

Puc. 1. Лim. 11.

Larysa Dovhan, Ph.D.(Pedagogy), Associate Professor of the Ukrainian and Foreign Languages Department, Vinnytsya National Agrarian University

\section{NON-FORMAL ADULT EDUCATION SYSTEM IN RURAL AREAS}

Rapidly changes in the socio-economic conditions of life necessitate constant advancement of knowledge, skills and abilities of a person. Strengthening of the person's ability to adapt to transformations in the economy, professional activities, culture and society is a goal that can be accomplished only through education. At the same time, the education system itself needs to be modernized.

Almost all modern societies provide a certain type of formal education system. These formal systems usually include a similar list of characteristics like compulsory attendance of training sessions, approved curricula, agreed methods and teaching methods. The educator usually takes control of the specification of the needs, development of goals and choice of the teaching methods. Formal education systems play an important and necessary role, but they are only one of the possible approaches to education.

Formation of a highly qualified specialist having high level of knowledge and skills, a desire for development and self-realization, creative thinking, etc. is influenced both by formal education and to a large extent by informal education.

Adult education is an integral part of lifelong education that provides a person with competitive abilities in the labor market, enables to solve a range of social problems and facilitating self-realization. In the adult education, the key position is occupied by non-formal education, access to which is practically unavailable to Ukrainian rural population.

Foreign experience shows that the system of non-formal education in rural areas successfully interacts with the system of agricultural extension service that has similar goals and objectives.

Informal education and the system of agricultural extension service can become an effective tool for improving the well-being of Ukrainian rural population under conditions of the state assistance and joined efforts of scientists, educators and advisers. extension.

Keywords: education; adult education; non-formal education; educational programs; rural areas; agricultural

П остановка проблеми. Об'єктивна необхідність докорінних перетворень в усіх сферах життя українського суспільства назріла уже давно. Усвідомлення того, що успішність цих трансформацій у стратегічній перспективі вимагає перегляду насамперед підходів до поширення, здобуття та впровадження знань дало старт сучасному процесу реформування системи національної освіти. Першими об'єктами змін стали дитяча дошкільна та шкільна освіта, а також вища освіта, споживачами послуг якої переважно є юнацтво та молодь.
Поза цими процесами, за окремими виключеннями, перебуває освіта дорослих. Винятки спостерігаються у тих сферах національного господарства, в яких відповідно до чинного законодавства збереглися вимоги до обов'язкового підвищення кваліфікації кадрів або для отримання певних кваліфікаційних допусків, уроботі служб зайнятості по перепідготовці кадрів та у проведенні певних комерційних заходів стихійної неформальної освіти.

Якщо про поширеність надання освітніх послуг дорослим у містах по окремих напрямах ще можна вести мову, то у сільській місцевості, де 
проживає третина українців (14,7 млн. чол.) доступ до них критично обмежений. Досвід багатьох країн свідчить, що дана проблема може бути успішно вирішена завдяки формуванню системи сільськогосподарського дорадництва та розвитку неформальної освіти на селі.

Аналіз досліджень і публікацій. Дослідженням історії, особливостей функціонування та перспектив розвитку неформальної освіти дорослих займалися В. Андрущенко, В. Давидова, Т. Десятов, А. Гончарук, С. Закревська, І. Колеснікова, Р. Колишко, О. Лазаренко, В. Луговий, Н. Махиня, Н. Ничкало та інші. Дослідженням питань формування системи сільськогосподарського дорадництва присвятили свої праці багато українських та зарубіжних вчених, серед яких О. Бородіна, A.B. Ван ден Бан (A.W. Van den Ban), С. Григорьєв, M. Кновлес (M. Knowles), Т. Кальна-Дубінюк, Р. Корінець, М. Кропивко, М. Лобанов, М. Лубяний, Б. Свонсон (В. Swanson), Б. Сіверс (В. Seavers), К. Хервег, (К. Herweg), Х. Хоукінс (H. Hawkins), О. Чаянов, Р. Шмідт та інші. Проте в наукових працях не були достатньо висвітлені питання формування системи сільськогосподарського дорадництва та неформальної освіти дорослих у сільській місцевості, що і зумовило вибір теми нашого дослідження.

Мета статті полягає у висвітленні позитивного досвіду сільськогосподарського дорадництва у вирішенні проблем розвитку неформальної освіти дорослих у сільській місцевості.

Виклад основного матеріалу. В сучасному науковому розумінні освіта - це процес та результат засвоєння особистістю певної системи наук, знань, практичних умінь і навичок та пов'язаного з ними того чи іншого рівня розвитку iii розумово-пізнавальної і творчої діяльності, а також моральної культури, які у своїй сукупності визначають соціальне обличчя й індивідуальну своєрідність цієї особистості [4].

Нині поняття “освіта” розуміється широко та окреслюється різними контекстами: освіта цінність (державна, суспільна, особистісна); система різноманітних навчальних закладів і освітніх установ; особливий процес; різнорівневий результат; соціокультурний феномен; соціальний інститут, що впливає на стан свідомості суспільства [1].

Існують три основні форми освіти [9]:

1) формальна освіта (formal education) початкова, загальна середня освіта, середня професійна освіта, вища освіта, освіта після закінчення ЗВО (аспірантура й докторантура), підвищення кваліфікації й перепідготовка фахівців і керівників з вищою і середньою професійною освітою в інститутах, на факультетах і курсах підвищення кваліфікації й професійної перепідготовки;

2) неформальна освіта (non-formal education) - професійно спрямовані й загальнокультурні курси навчання в центрах освіти, на різних курсах інтенсивного навчання, семінарах, майстеркласах. У відповідності 3 класифікацією ЮНЕСКО до неформальної освіти належать навчальні програми, курси, семінари, гуртки, лекторії, що організовуються і проводяться поза традиційною системою освіти. Неформальна освіта відбувається у межах формального офіційного середовища, але не $є$ офіційно визнаною, результати навчання не завжди підтверджуються відповідними документами.

3) інформальна освіта (informal education) $€$ загальним терміном для освіти за межами стандартного освітнього середовища індивідуальна пізнавальна діяльність, що супроводжує повсякденне життя, реалізується за рахунок власної активності індивідів в оточуючому культурно-освітньому середовищі; спілкування, читання, відвідування установ культури, подорожі, засоби масової інформації тощо. При цьому людина перетворює освітні потенціали суспільства в дієві чинники свого розвитку.

Майже усі сучасні суспільства забезпечують певний тип формальної системи освіти. Опис цих формальних систем зазвичай дає подібний перелік характеристик: обов'язкове відвідування навчальних занять, затверджені навчальні плани, узгоджені методи і способи навчання. Той хто навчає приймає на себе контроль визначення потреб, розробку цілей та вибір методів і способів навчання. Системи формальної освіти відіграють важливута необхіднуроль, але вони є лише одним із можливих підходів в освіті.

На формування висококваліфікованого працівника, якомупритаманні високий рівень знань та навичок, прагнення розвитку та самореалізації, креативне мислення тощо, впливає не тільки формальна освіта, але й у великій мірі неформальна освіта [6].

Розвитку неформальної освіти сприяють світові організації, зокрема ООН, ЮНІСЕФ, ЮНЕСКО, Свропейський Союз, Рада Європи та інші. Саме тому неформальна освіта більш розвинена в Європі та сприймається європейськими роботодавцями на рівні 3 формальною освітою [5].

Наразі, стрімкий розвиток неформальної освіти як практики навчально-виховної діяльності та 


\section{СИСТЕМА НЕФОРМАЛЬНОЇ ОСВІТИ ДОРОСЛИХ У СІЛЬСЬКІЙ МІСЦЕВОСТІ}

сфери наукових педагогічних досліджень зумовлений:

- атрибутивністю (обов'язковістю, невід’ємністю) освіти для людині у сучасному інформаційному суспільстві;

- педагогізацією тих сфер професійної діяльності, які раніше не потребували засвоєння соціально-педагогічних функцій;

- зростанням ролі освіти й освіченості в українському суспільстві;

- нерівністю доступу до освітніх ресурсів соціально виключених категорій населення;

- усвідомленим прагненням людей до особистісного зростання, саморозвитку, самореалізації;

- стихійним розвитком досвіду неформальної освіти в суспільстві [7].

Обмежений доступ населення, яке проживає у сільській місцевості до освітніх послуг спонукає до пошуку нових шляхів поширення знань та інформації.

Знання можуть бути отримані за допомогою існуючої мережі закладів формальної та неформальної освіти, завдяки самоосвіті, різноманітних наявних інформаційних джерел, але забезпечити безперервність та системність отримання освітніх та інформаційних послуг сільським населенням, спростити та зробити цей процес ефективнішим може тільки чітко вибудована інформаційно-освітня система. Світовий досвід переконує, що успішним прикладом такої системи є існуючі у понад 130 країнах світу служби розповсюдження знань досвіду в сільській місцевості (сільськогосподарської дорадчої діяльності, сільськогосподарського дорадництва, “Екстеншн”, агроконсалтингу) [2].

У вузькому розумінні сільськогосподарське дорадництво $є$ інформаційно-освітньою системою, яка забезпечує у сільській місцевості потреби товаровиробників та населення упідвищенні рівня знань та удосконаленні навичок, необхідних для прибуткового ведення господарства. Більш широке та сучасне розуміння не обмежує сільськогосподарське дорадництво завданням підвищення ефективності господарської діяльності та розширює його до покращення всіх аспектів життя селянина.

Погляди на основні завдання сільськогосподарського дорадництва у різних країнах дещо відрізняються. У США ці завдання мають чітко виражену освітню роль, оскільки сільськогосподарське дорадництво розглядається як частина системи освіти дорослих. Сільськогосподарські дорадники більшості європейських країн до недавнього часу основне своє завдання вбачали у наданні допомоги фермерам у вирішенні їхніх проблем та покращенні ефективності діяльності ферм. У країнах, які є менш економічно розвинутими, сільськогосподарське дорадництво, у першу чергу, сприяє впровадженню сучасних сільськогосподарських технологій, які дозволяють збільшити обсяги виробництва продовольства [11].

Підвищення економічної ефективності сільськогосподарського виробництва хоча й залишається важливим завданням, однак перестає бути визначальним і розглядається у контексті тих засобів, які використані для його досягнення. Головним чином, ці засоби мають базуватися на знаннях. У такому випадку будуть досягнуті не тільки економічні, але й соціальні та інші цілі сталого розвитку.

Зокрема, стратегія соціально-економічного розвитку Європейського союзу “Європа-2020” визначає три нових фактори зміцнення економіки: зростання, базоване на знаннях та інноваціях; соціальне залучення та висока зайнятість; “'зелений розвиток” або стала і конкурентна економіка [8].

Спільним у філософії сільськогосподарського дорадництва різних країн $є$ досягнення позитивних змін у житті селян на рівноправних умовах завдяки неформальній освіті за допомогою впровадження сучасних досягнень аграрної науки (рис. 1).

Поширення знань щодо біоенергетики, біотехнологій, кліматичних змін, здоров'я та харчування людей, управління природними ресурсами, торгівлі та ринків, підвищення рівня знань та впровадження інновацій на рівні громад, а також поліпшення становища жінок на селі сприяє зменшенню бідності, покращенню рівня життя населення у сільській місцевості та сталості екологічного, соціального та економічного розвитку сільських територій.

Сільськогосподарські дорадчі служби та сільськогосподарські дорадники намагаються змінити поведінку селян через навчання та комунікації. Неформальні освітні програми $є$ основним інструментом досягнення цієї мети. У світовій практиці сільськогосподарські дорадчі служби є тими “низовими” організаціями, які відповідно до потреб і проблем селян забезпечують функціонування у сільській місцевості системи обміну інформацією та освітніми ресурсами, здобуття нових знань та формування навичок необхідних для того, щоб працювати краще як на самого себе, так і на громаду. Неформальний підхід до освіти розширює можливість селян брати на себе відповідальність за рівень власного добробуту та якості життя.

Необхідно розуміти, що надання інформації дорадчою службою не обов'язково робить 


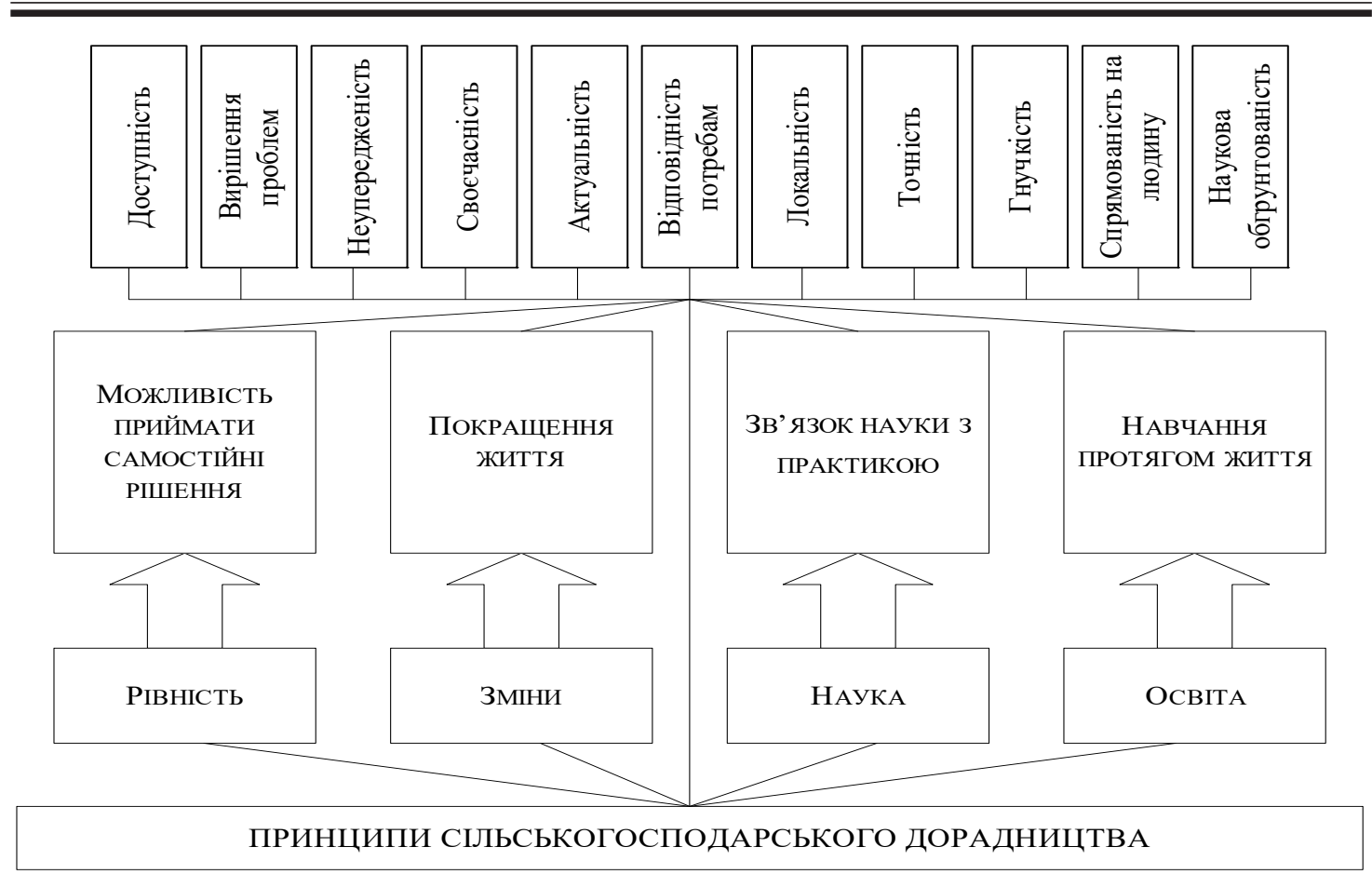

Рис. 1. Філософія сільськогосподарського дорадництва

Джерело: сформовано автором на основі джерела [10]

успішним, але надає більше коло можливостей для цього. Коли сільськогосподарський товаровиробник або селянин починає усвідомлювати власні сили, силу місцевої громади, розуміти закони та принципи ведення ефективної господарської діяльності, саме тоді він стає готовим до впровадження змін, які покращать його життя [3].

Цільовою аудиторією освітніх програм $є$ сільське населення усіх вікових категорій. Обов'язковість формальної дошкільної та шкільної освіти й наявність широкої мережі інституцій неформальної дитячої, юнацької та молодіжної освіти дозволяють сільськогосподарським дорадникам приділити більше уваги неформальній освіті дорослих селян: фермерів, членів їх сімей, жителів сільської місцевості.

Розробка та реалізація освітніх програм передбачає врахування особливостей неформальної освіти, специфіки навчання і виховання дорослих. Неформальні програми освіти дорослого сільського населення сільськогосподарських дорадчих служб вирізняються наступним:

1. Підхід орієнтований на учнів. Акцент програми зосереджується на навчальній діяльності, а не на навчанні, яке відбувається. Учень активно бере участь у навчальному процесі та допомагає у розробці цілей, визначенні змісту та методології програми.
2. Параметри навчальних програм демонструють різноманітність і гнучкість. Важливим аспектом неформальної освіти дорослих є те, що вона практична, гнучка і базується на потребах учасників.

3. Неформальна освіта базується на взаємній повазі та довірі. Навчальне середовище підтримує інтерактивний процес. Вчитель не тільки планує вчити учнів, а й вчитися у них. Учні часто беруть на себе роль педагога.

4. Використання локальних ресурсів сприяе зменшенню витрат без втрати якості програм. Неформальна освіта вирішує проблеми творчо через використання наявних ресурсів.

5. Систематична та постійна участь у всіх неформальних освітніх програмах селянину не потрібна. Важливими є своєчасність і корисність програми. Учасникам потрібна інформація для вирішення проблем і прийняття рішень, а не для вивчення ізольованих навичок або знань. Учасники можуть залишити програму, якщо не бачать можливості безпосереднього використання результатів або особистої цінності.

6. Багато неформальних освітніх програм, на відміну від формальної освіти, мають нижчий рівень структурованості. Щоб заохотити і розвивати підхід, орієнтований на учнів, вчитель повинен бути не тільки гнучким, а й готовим поділитися контролем [10]. 
Таким чином, сільськогосподарські дорадники, які залучаються до планування та виконання освітніх програм, мають не тільки розуміти принципи та механізм функціонування системи сільськогосподарського дорадництва, володіти адекватними фаховими знаннями у сфері надання дорадчих послуг, але й, що не менш важливо, бути педагогами. Тому досить часто до освітнього процесу у сільськогосподарському дорадництві залучаються викладачі закладів вищої освіти та педагоги, які уже вийшли на пенсію. У США, наприклад, сільськогосподарські дорадчі служби функціонують при державних університетах і участь у неформальних освітніх програмах для дорослих селян $є$ складовою частиною посадових обов'язків викладачів цих навчальних закладів.

Сільськогосподарське дорадництво є одним із інструментів досягнення цілей аграрної політики Свропейського Союзу, які передбачають поліпшення соціального добробутута полегшення доступу селян до засобів існування, посилення мультиплікативних ефектів, пов'язаних із розвитком економіки сільського господарства, посилення усвідомлення впливу екологічних та культурних аспектів розвитку сільської місцевості, удосконалення систем розповсюдження знань та інформації серед селян тощо.

Висновки. Швидко мінливі соціально-економічні умови життя зумовлюють необхідність постійного оновлення знань, навичок та вмінь людини. Зміцнення iї здатності адаптуватися до перетворень в економіці, професійній діяльності, культурі та суспільстві $€$ завданням, яке може буги виконано, на нашу думку, лише за допомогою освіти. Водночас модернізації потребує і сама система освіти.

Освіта дорослих є складовою частиною освіти впродовж життя, яка забезпечує людині конкурентоздатність на ринку праці, дозволяє вирішувати значне коло суспільних проблем та сприяє їі самореалізації. В освіті дорослих ключову роль відіграє неформальна освіта, доступ до якої в українських селян практично відсутній. Закордонний досвід свідчить, що система неформальної освіти в сільській місцевості успішно взаємодіє із системою сільськогосподарського дорадництва, яка має схожі цілі та завдання.

Неформальна освіта тасистема сільськогосподарського дорадництваможугьстати ефективним інструментом покращення добробуту українських селян за умови державного сприяння та поєднання зусиль науковців, освітян і дорадників.

\section{ЛІТЕРАТУРА}

1. Гриневич Л. М. Поняття “освіта”, “розвиток освіти”, “освітня політика" в сучасному науковому дискурсі. Неперервна професійна освіта: теорія і практика. 2015. № 1-2 (4243). С. $14-19$.

2. Довгань Л. І., Довгань Ю.В. Система сільськогосподарського дорадництва як інструмент покращення добробуту сільського населення. Інфраструктура ринку. 2018. № 17 URL: http://market-infr.od.ua/uk/17-2018.

3. Довгань Л.І., Довгань Ю.В. Роль сільськогосподарського дорадництва у досягненні цілей політики сталого розвитку. Інфраструктура ринку. 2018. № 25. URL: http:/ /www.market-infr.od.ua/uk/25-2018.

4. Енциклопедія освіти. Акад. пед. наук України; відп. ред. В. Г. Кремень. Київ: Юрінком Інтер, 2008. $1040 \mathrm{c}$.

5. Журавель Т., Рогозна М. Неформальна освіта як інструмент підвищення лідерського потенціалу учнів ПТНЗ. Освітологічний дискурс. 2018. № 1-2 (20-21). URL: http:// od.kubg.edu.ua/index.php/ journal/article/view/496/ 410.

6. Коваленко М.О. Теоретико-методичні аспекти державного регулювання розвитку неформальної освіти в Україні. Науковий вісник Херсонського державного університету. Серія: Економічні науки. 2015. Вип. 10 (Ч. 2). С. 186 -189 .

7. Павлик Н. П. Неформальна освіта як сфера наукового пізнання. Вісник Житомирського державного університету. Серія: Педагогічні науки. 2015. Вип. 2 (80). С. 53 - 58.

8. Europeans, Agriculture and the Common Agricultural Policy (CAP). URL: http://ec.europa.eu/ commfrontoffice/publicopinion/archives/ ebs/ ebs_410_en.pdf.

9. The impact of non-formal education on young people and society. URL: https://www.aegee.org/wpcontent/uploads/publications/ NFE_book.pdf.

10. Seevers B., Graham, D., Gamon, J. \& Conklin, N. Education through Cooperative Extension Washington, DC: Delmar Publishers, 1997. 288 p.

11. Van den Ban A.W. \& Hawkins, H. S. Agricultural Extension. Malden, MA: Blackwell Science, 1996. 294 p.

\section{REFERENCES}

1. Hrynevych, L. M. (2015). Poniattia "osvita", "rozvytok osvity", "osvitnia polityka" v suchasnomu naukovomu dyskursi [Notions "education", "development of education", "education policy" in the modern scientific discourse]. Continuous Professional Education: Theory and Practice. Vol. 1-2 (42-43), pp. 14 - 19. [in Ukrainian].

2. Dovhan, L.I. \& Dovhan, Yu.V. (2018). Systema 
silskohospodarskoho doradnytstva yak instrument pokrashchennia dobrobutu silskoho naselennia [Agricultural extension system as an instrument for improvement of the rural population welfare]. Market Infrastructure. Vol. 17. [Electronic resource]. Available at: http://market-infr.od.ua/uk/17-2018. [in Ukrainian].

3. Dovhan, L.I. \& Dovhan, Yu.V. (2018). Rol silskohospodarskoho doradnytstva u dosiahnenni tsilei polityky staloho rozvytku [The role of agricultural extension for achieving goals of sustainable development policy]. Market Infrastructure. Vol. 25. [Electronic resource]. Available at: http:// www.market-infr.od.ua/uk/25-2018. [in Ukrainian].

4. Kremin, V.G. (Ed.). (2008). Entsyklopediia osvity [Encyclopedia of Education]. Acad. Ped. Sciences of Ukraine. Kyiv: Yurinkom Inter, 1040 p. [in Ukrainian].

5. Zhuravel, T. \& Rohozna, M. (2018). Neformalna osvita yak instrument pidvyshchennia liderskoho potentsialu uchniv PTNZ [Non-formal education as a tool of increasing leader potential of students in professionally technical educational institutions]. Educational discourse. Vol. 1-2 (2021). [Electronic resource]. Available at: http:// od.kubg.edu.ua/index.php/ journal/article/view/496/ 410. [in Ukrainian].

6. Kovalenko, M.O. (2015). Teoretyko- metodychni aspekty derzhavnoho rehuliuvannia rozvytku neformalnoi osvity v Ukraini [Theoreticmethodical aspects of government regulation of the development of informal education in Ukraine]. Scientific Bulletin of Kherson State University. Series: Economic Sciences. Vol. 10 (P. 2), pp. 186 - 189. [in Ukrainian].

7. Pavlyk, N. P. (2015). Neformalna osvita yak sfera naukovoho piznannia [Non-formal education as the sphere of scientific knowledge]. Bulletin of Zhytomyr State University. Series: Pedagogical Sciences. Vol. 2 (80), pp. 53 - 58. [in Ukrainian].

8. Europeans, Agriculture and the Common Agricultural Policy (CAP) (2014). [Electronic resource]. Available at: http://ec.europa.eu/ commfrontoffice/publicopinion/ archives/ebs/ ebs_410_en.pdf. [in English].

9. The Impact of non-formal education on young people and society (2014). [Electronic resource]. Available at: https://www.aegee.org/wp-content/ uploads/publications/NFE_book.pdf. [in English].

10. Seevers, B., Graham, D., Gamon, J. \& Conklin, N. (1996). Education through Cooperative Extension. Washington, DC: Delmar Publishers, 288 p. [in English].

11. Van den Ban, A.W. \& Hawkins, H.S. (1996). Agricultural Extension. Malden, MA: Blackwell Science, 294 p. [in English].

Стаття надійшла до редакції 15.02.2019

\section{G58080.2058080}

"Навчати народ - значить робити його қраще; просвіщати народ - значить підвищувати його моральність; робити його грамотним - значить иивілізувати його".

Biктор Тюго

французький письменник.

“В ^юдині, яку ми виховуємо, повинні поєднуватися моральна чистота, духовне багатство, бозична досқоналість".

Василь Сухомлинський український педагог, публіщист, письменник, поет

“Всі творіння природи досягають довершеності хише у певну пору: попереду того вони зріють, опісля - псуються. ТТа твори мистецтва рідко бувають такими, цоб йх не можна було поліпшити. Леревага доброго смаку - здатність насолоджуватися речами лише в їхньому завершеному вигляді; не қожному вона дана, а іншому й дана, та нерозвинута. Навіть у плодах розуму є своя найвища ступінь зрілості: вмій ї розпізнати, щоб ӥ̈ поцінувати й себе розвинути".

Бальтасар Трасіан-і-Моралес іспанський письменник, мислитель, білособ та теоретиклітератури

\section{G58080}

